\title{
THE WORLD OF DON SANTO
}

\author{
by
}

Veiko Valencia

\author{
A thesis \\ submitted in partial fulfillment \\ of the requirements for the degree of \\ Master of Fine Arts, Visual Arts \\ Boise State University
}

May 2017 
(C) 2017

Veiko Valencia

ALL RIGHTS RESERVED 


\section{BOISE STATE UNIVERSITY GRADUATE COLLEGE}

\section{DEFENSE COMMITTEE AND FINAL READING APPROVALS}

of the thesis submitted by

\section{Veiko Valencia}

Thesis Title: The World of Don Santo

Date of Final Oral Examination: $\quad$ 01 March 2017

The following individuals read and discussed the thesis submitted by student Veiko Valencia, and they evaluated his presentation and response to questions during the final oral examination. They found that the student passed the final oral examination.

Stephanie, Bacon, M.F.A.

Chair, Supervisory Committee

Chad Erpelding M.F.A.

Member, Supervisory Committee

Lily Lee, M.F.A.

Member, Supervisory Committee

Kate Walker, M.F.A.

Member, Supervisory Committee

The final reading approval of the thesis was granted by Stephanie, Bacon, M.F.A., Chair of the Supervisory Committee. The thesis was approved by the Graduate College. 


\section{DEDICATION}

TO SUSU. My best friend, partner in crime, editor, curator, PR, GPS, stern critic, and wife, without your loving support I wouldn't have even tried. 


\section{ACKNOWLEDGEMENTS}

Because this thesis wouldn't have been possible without the help of such great people, thank you Everyone, to Richard and Cheryl who I consider my artistic parents. To Dan, who I guess will be my artistic Uncle, thank you for always being there to help me clarify my ideas. To my committee for their constant criticism and support, thank you Stephanie for starting a sincere dialogue with Don Santo. To Kate for encouraging me to make Don Santo real, thank you Lily and Chad for offering different solutions to my work when I was stuck. To Jill for helping me create the first cheap version of Don Santo. To Shawn for giving the voice to La Matriz. Thank you to Craig and Niharika for always sharing specific essays and books related to Don Santo. Thank you to all my classmates for sharing the studios and not locking your doors. Entering to each of your studios was like entering into a Pandora's box every day, lots of ideas to copy. I want to thank my undergrad classmates as well, because with your questions you also helped me to unlock some problems in my work. To Laurie for your confidence in me to teach the labs, and to my good friend Don Winiecki who taught me an interesting definition of being an intellectual. I want to thank my family, my brother for always sharing new books with me. To my mom who has always being there since I decided to pursue the career of the arts and now she gave the voice to the USER. Finally, I want to thank Mr. Barry and Brandon for their constant support and humor. 


\begin{abstract}
The following paper is an investigation on the legacy of colonization, exploring the question of how to produce an object without the colonizers' presence. By creating fictional characters, myths, and a fake computer software I am proposing a different way to respond to this question. Using the notion of the copy as the core to this alternative response, I am exploring the idea that the copy of the copy at some point can become its own original.
\end{abstract}




\section{TABLE OF CONTENTS}

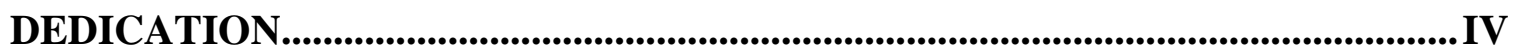

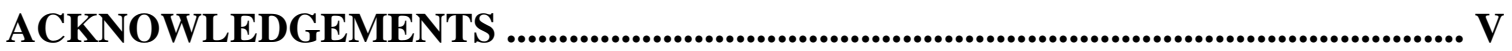

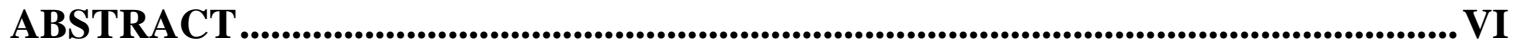

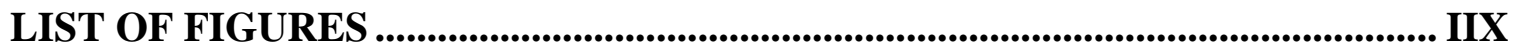

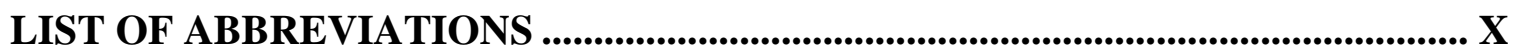

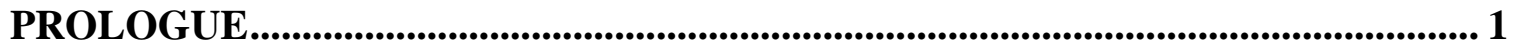

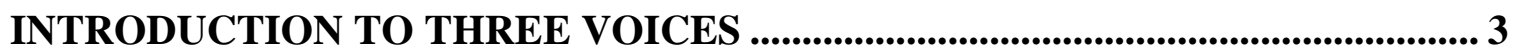

[ INTRODUCTION TO COLONIAL PHOTOSHOP MANUAL ] .............................. 6

I ) [ INSTALLING COLONIAL PHOTOSHOP ]............................................................. 9

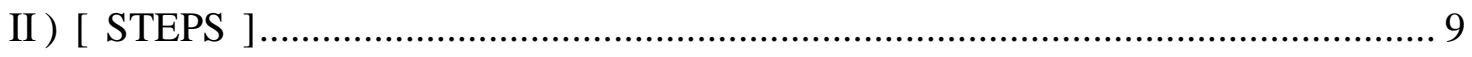

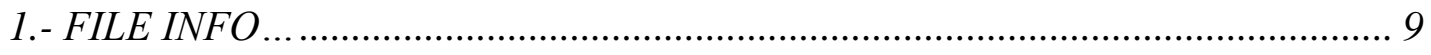

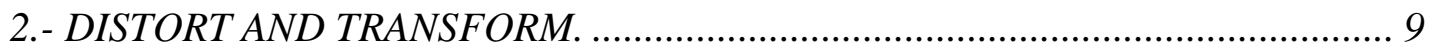

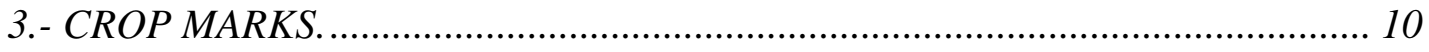

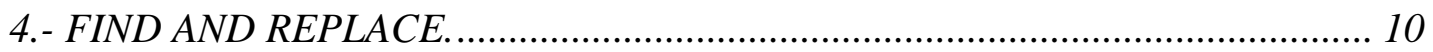

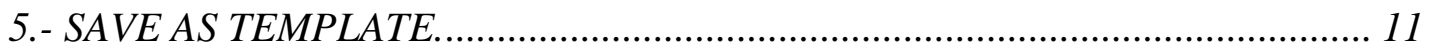

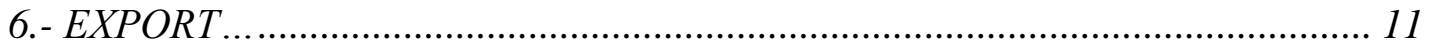

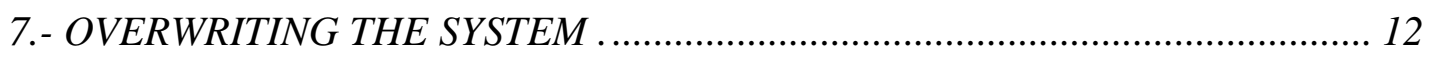

III) [ RESTART THE SYSTEM ] ………………………............................ 12

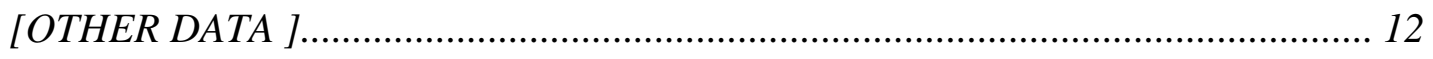

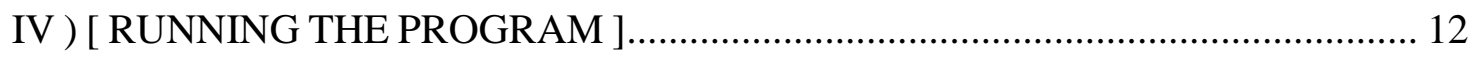




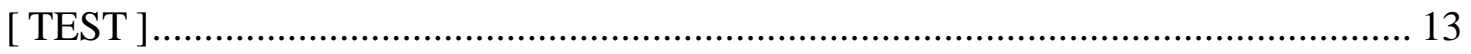

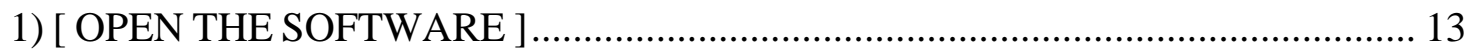

3) [ VIEW RECENT IMPORTED FILES ] ..................................................... 13

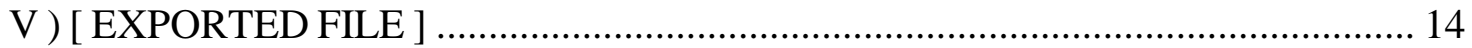

VI ) [ FREQUENTLY ASKED QUESTIONS ] ............................................... 14

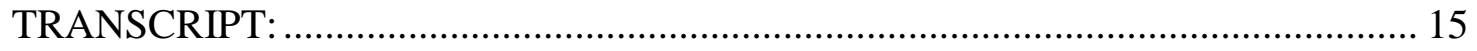

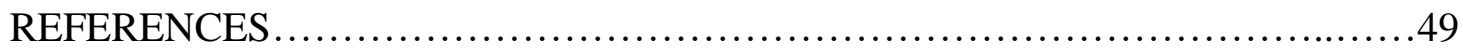




\section{LIST OF FIGURES}

Figure 1. Geronimo de Leon, San Martin Obispo y Confesor, 1894 ............... 2

Figure 2. The Sacred Image of Señor de Huanca, Anonymous....................14

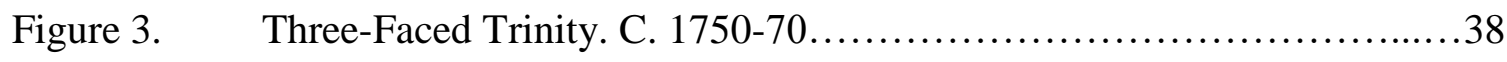

Figure 4. Francisco de Zurbaran, Cristo Recogiendo sus Vestiduras. 1161_.......39

Figure 5. The Sacred Image of Señor de Huanca, Anonymous....................40 


\section{LIST OF ABBREVIATIONS}

$\begin{array}{ll}\text { CPS } & \text { Colonial Photoshop Software } \\ \text { DS } & \text { Don Santo } \\ \text { LM } & \text { La Matriz } \\ \text { U } & \text { User } \\ \text { BS } & \text { Bigger Software } \\ \text { SS } & \text { Small Software }\end{array}$




\section{PROLOGUE}

Everything started when my wife and I were coming back from an art show in Las Vegas. In our return we decided to skip the highway and instead we took a short cut. During our trip, there were no cars behind or ahead of us. We were alone most of time. It was all desert. That's when it occurred to me that it would be nice if there was a monument or landmark to visit, like the Spiral Jetty in Rozel Point. Suddenly, I had the idea that only a statue or an image of a saint could remind people that this was a sacred place. I wanted to stop and explore the land for possible locations, but at that moment I did not have a statue or an image of a saint to leave there. I never stopped thinking about that idea. Those empty places were perfect locations to set some Saints, I thought. But the idea that bothered me the most, was that I did not know what kind of Saint to leave there. Should it be female, like Santa Rosa de Lima? Black, like San Martin de Porres? Native American? And the more I thought about it the more I was rejecting the project. It was too stressful. I started to regret the idea but that's when it occurred to me, why not make my own Saint? It was a ridiculous idea, but just to think about the many possibilities that this option could offer me encouraged me even more.

Therefore, once I was back in town I was walking around thrift stores. I was looking for a subject or theme to make a painting. I was not completely sure what I was looking for either. I just knew that I needed to keep looking. That's when I saw it. It was in the kitchen section among dishes, cups and utensils. I remember that my first thought was, this is so bad. It was a tiny, disproportionate sculpture of what seemed to be a Roman soldier with an old nude man. What made me laugh was that the Roman soldier seemed to be posing and looking at a camera with one eye bigger than the other. And the old man had one arm larger than the other.

I took it to the studio and I made a painting about it. Then I made a copy of the first painting. After finishing that copy, I copied it again but now adding a landscape as a background from another thrift store painting. Finally, I copied the outcome of that 
combination again. That's how Don Santo was born. It is the result of the copy of the copy.

Not that long ago, I discovered that the statue of the Roman soldier with a nude man belonged to an already popular saint. In Latin America this popular Saint is known as San Martin Caballero, although, a friend told that it could also be the painting from Zacatecas, Mexico, 'San Martin Obispo y Confesor' by Geronimo de Leon painted in 1894.

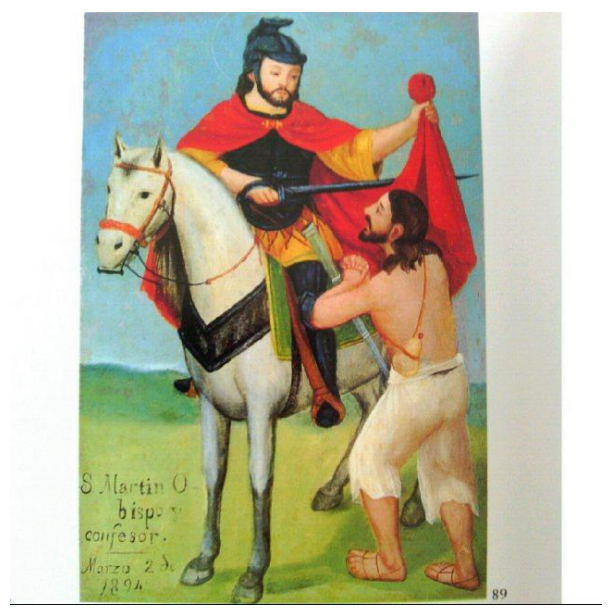

Figure 1. Geronimo de Leon, San Martin Obispo y Confesor. 1894. Oil on tin 14” x 11". But doing my research I found out that it is probably 'Saint Martin and the Beggar' by el Greco or maybe by Anthony Van Dyck. This is a difficult task, hard to decipher. But it is clear that before San Martin Caballero was San Martin Caballero it was Saint Martin de Tours. However, all the information that we can obtain from Saint Martin de Tours comes from his hagiographer, Sulpicius Severus c. 363 -c. 425 . According to the stories, Severus might have invented Saint Martin de Tours to promote his own ideas. ${ }^{i}$ Then, Saint Martin de Tours was also a fictional character. At the beginning I was sad to hear that my saint was a copycat of San Martin Caballero. But when I discovered that I was not the first one, that at some point Saint Martin de Tours was like Don Santo, I saw new possibilities. It is when I started to look at this project differently, that I started to embrace and celebrate the similarities, not to prove that there is not such a thing as an original in this world, but instead to show how the copy can still look like the original and still be so different. This is when I started to investigate the visual etymology of all the Saints from Latin America and what I found was amazing. I discovered a world of great bad original copies. 


\section{INTRODUCTION TO THREE VOICES}

["The trickster reminds us there is no single way to play...literally fooling around to discover new paradigms and even new logics."]

Mythical Trickster Figures:

Contours, Contexts, and Criticism

This project is a theoretical and historical study of the notion of the copy. The intention of exploring the copy this way is to demonstrate that when the copy is continuously copied, it can reach a point where it can not be connected to the first source or original anymore. Once it reaches that point, the copy will have become its own original. The reasons this occurs, is because in the act of copying, when the copy is being copied, it enters into a subtractive and additive process. It also builds a new body of stories or anecdotes around it and the combination of these activities eventually will build the way to the original copy.

However, in order to explain this idea of the copy of the copy as a new original, I need to establish some ground. Therefore, I explore the colonial paintings of Latin America, because Latin America was conquered by copies and myths. During the process of colonization the colonizers wanted to insert Catholicism in the Americas. They found the way to do it through images. These images were paintings of European saints. However, they did not send the original paintings, instead they sent copies of copies of these original saints. That's why today there is a copy of Caravaggio in a Church in Mexico. ${ }^{\text {ii }}$ Not only that, the colonizers also made up some myths and legends about the apparition of these images. Their goal was to sell the idea that colonization was a divine order. Many of those copies sent by the colonizers are known today with different names and stories. It all depends on their location, because they developed their identity through their locality. Through the study of these images I have also identified a repetitive path in the colonizer's way to operate. These are the seven methods of colonization. 
Trying to portray the idea of the copy of the copy and the methods of colonization has been very difficult. I wanted to find a metaphor that allowed me to represent this project historically and at the same time contemporarily, because colonization hasn't stopped, it has transformed. Therefore, this project is the metaphorical representation of the Holy Trinity combined with computer software.

The Holy Trinity is a Catholic belief where God embodies three different persons. As with this Catholic belief, this project contains three different voices in a single body. And the computer software is called Colonial Photoshop, because the main job of the process of colonization in Latin America was to overlay the locals' culture with theirs. This computer software is the vivid representation of how the generation of information actually works. For instance, the illusion of a paper in your screen is right in front of you. Some buttons or icons intend to convince you that they have an actual relief, and that a source of light is coming from one side of your screen. And beneath the illusion there is another world of codes that contain how the information is collected and organized. This world of codes is nothing without the illusion. It simply can't exist. However, the combination of these two are nothing if they do not have the User, someone that activates them. The User who thinks it is in control of everything when in reality this User is being utilized by La Matriz and persuaded by the illusion (Don Santo). This User only adapts its knowledge to the other two.

This is how I arrive at the idea of the Holy Trinity. This computer software was designed by three different voices: Don Santo, La Matriz, and the User. Don Santo is the seller and designer of the illusion of the software. He is the one who has to persuade the customer into purchasing this product. He is the layer that everyone sees. He is the fiction world or as we call it today, the alternative fact. He is in charge of making you understand the real world through the fiction, as Miguel de Cervantes did when he wrote Don Quixote ${ }^{\mathrm{iii}}$. The second voice is La Matriz. This one belongs to the world of the actual facts, the non-fiction world. Its voice is behind Don Santo's world. Because the only way to access the Legacy of Colonization is through the illusion, by digging on the simulacrum. As I mentioned before, Latin America did not exist, it was invented by copies and myths. Then, the actual facts can't argue with the alternative facts. Instead they need to adapt and accommodate to the Fiction World. 
Finally, the third voice is called User. This voice is the one that exist in between the real and fake world. It is the one that absorbs both worlds. It exists in an interactive zone. It has the information of historical facts, domestic experiences, and fictional events. In this interactive zone one can experience the combination of the real and the fake. This combination is the fabrication of a new real-fake world. It is in this world where the process of decolonization can actually begin. But it can not exist without the three layers. As in the Saint Trinity, 'One God in three divine Persons'.

In the name of father, And of the Son, And of the Holy Spirit, Amen,

Veiko 


\section{[ INTRODUCTION TO COLONIAL PHOTOSHOP MANUAL ]}

[ "He who controls the past controls the future. He who controls the present controls the past."]

George Orwell. 1984

(CLICK HERE)

Dear Valued Customer,

As with any computer in the world, in order to function societies also need an operating system. This operating system is the software that controls and defines how the computer performs each of its tasks. Through history we have seen how these softwares operate. We have seen them fail and disappear. Others are obsolete waiting to be reactivated, while others are still active due to their modernization. The majority of computers or societies of today tend to stay with the same operating system. The pressure from other operating systems that become more sophisticated obligates them to change or update their software. This pressure comes at a high price that sometimes the user can't afford to pay.

Hello, my name is Don Santo and I am the creator of the Colonial Photoshop software. I am part of the local team that works together with other smaller groups of operating systems. I have appeared because many of the older and smaller operating systems out there are being arbitrarily isolated and absorbed by bigger ones. ${ }^{1}$ (CLICK HERE) Due to this pressure and forms of control from Bigger Software, the market was expanding, but this expansion was at the cost of the Smaller Softwares. This situation left the users with fewer chances to obtain technical support in case of problems, forcing these clients to avoid consuming the products of the smaller softwares. That's why I designed the C.P. software. I am offering you a new product in the market that will help to reduce

\footnotetext{
${ }^{1}$ La Matriz. CODEX MANUAL. Local vs Global.
} 
the power of Bigger Software. However, in order to avoid being overwhelmed by the Bigger Software, the C.P. software looks for a space in the market by copying the methods and conventions of Bigger Software. ${ }^{2}$ (CLICK HERE)

This is how the C.P. software operates. It drains the power of Bigger Software in order to survive, because we understand that to compete at the same level with Bigger Software is almost impossible. It basically owns the market. That's why the C.P. software's foundations are a copy of Bigger Software's foundations. In our local team we understand that we do not have the reputation and reviews that Bigger Software has. We also do not have the resources to distribute our product as Bigger Software. Also, there is little information in the web about us, and about our product. That's why I have uploaded the C.P. software on the web to be downloaded for free at any time. You can try it out for 30 days, free of charge. Besides, if you are not satisfied, you can always delete it at any moment. No strings attached. We also understand that it can be a little stressful and complicated to download a new product from the web. That's why my team and I have provided you with the easiest way to guide you through this process. For instance, for the installation process there are only seven steps to follow. I even gave you some information about what to expect when the software is refreshing in your system.

However, as any other software the C.P. software is not immune from being infected by viruses. Sometimes invalid and fake links camouflage themselves during the installation process, and manage to access the system. Again, my team and I are aware of this situation that's why I have provided you with a list of common viruses to look at. Also, the C.P. software comes with a free cure that is active at all times. This cure will automatically start scanning and eliminating any sort of virus, hourly, weekly, monthly, it is up to you. That's right, with the C.P. software you will have full control of the information that comes in and out of your hardware.

\footnotetext{
${ }^{2}$ La Matriz. CODEX MANUAL. Copying.
} 
It is important that you know this information because every operating system controls the information that is being saved and deleted. This is what Bigger Software does not tell you. It never asks for your opinion every time it uninstalls other software. Therefore, it is crucial that you follow the steps carefully. For instance, most of the Bigger Software downloads files automatically, but sometimes some of these files are checked erroneously as dangerous and are omitted from the system without you knowing. This is the kind of event that you won't experience with the C.P. software, because it will tell you every time a new software enters into the market. It will immediately make a copy of this new software, so you can review it later at your convenience.

Now that you are aware of the reasons of why my team and I created the C.P. software, please do not forget to check the last pages of the manual with the FAO. In here you can find information of your interest. Not only about the C.P. software, but about other related information and other softwares as well. It is also very important that you check our website for current updates. This is up to you but if you want to avoid viruses we have a link with different cures. Also, do not forget to renew your subscription to get new information about our new products. With no more information to give you, In the name of my team and myself, I want to congratulate you for starting this new journey with the C.P. software.

Sincerely,

Don Santo 


\section{I ) [ INSTALLING COLONIAL PHOTOSHOP ]}

Great! You have definitively taken the first step on this amazing journey. First, you need to go to our website and download the file to install the C.P. software. I have copied a direct link to the file in here:

http://colonialphotoshop.blogspot.com/

Once you download the file you will have a series of archives that will need to be installed in a predetermined order. Opening and navigating through these different files can get a little complicated, but do not worry; I will guide you through the whole process of the installation. ${ }^{3}$ (CLICK HERE)

\section{II ) $[$ STEPS ]}

\section{1.- FILE INFO...}

Now that the file has been successfully downloaded into the system go to your Desktop and open My Documents. Then, open the Downloads folder and search for the following file:

There were no Coincidences Everything was Rigorously Planned CP.ZIP

This is the file that contains all the archives of the C.P program. Double click on it and it will start unpacking all the different archives into your system. Just click YES to everything. This process will take a few minutes because it is a large file. ${ }^{4}$

\section{2.- DISTORT AND TRANSFORM.}

Once the installation is completed and all the information from the C.P. software has been unpacked, open the $C_{-}$P_Archive folder and you will see a series of files in it. Be careful here because these files are not in order. You have to install them in a proper order. Search for the following file and double click on it.

Nothing was in Vain As in a Puzzle Every Piece Matters.SWP

\footnotetext{
${ }^{3}$ La Matriz. CODEX MANUAL. Parafiction.

${ }^{4}$ La Matriz. CODEX MANUAL. File EXE.
} 
Something to notice here is that once you double click on that file it will tell you that this file is not compatible with the system. Just click IGNORE TO ALL and it will continue with the application. ${ }^{5}$

3.- CROP MARKS.

Since the C.P. software is not a dependable software, it won't be compatible with any general system. That's why, it is important that you go back to the C_P_Archive folder and search for the following file:

Once Everything is Settled the Territory Needs to be Secured.MAX

Open the file and wait until the installation is fully completed. Failing to do this can lead to either an incomplete installation or failure to operate the program completely with all its properties. ${ }^{6}$

4.- FIND AND REPLACE.

Aside from the general requirements, to run the C.P. software, it requires you to do an unusual step. Go one more time to your C_P_Archive folder and search for the README folder. Open it and search for the following file:

Fake Stories are the Best Way to Distract the People from the Major issues.TX I

Open this file and a message will pop up telling you that this file contains important information about the C.P. software. It will also tell you to read the information before to continuing with the installation. Just click ACCEPT to all of them, then the file will open on a README text page. Go through that page, skimming it and right before the

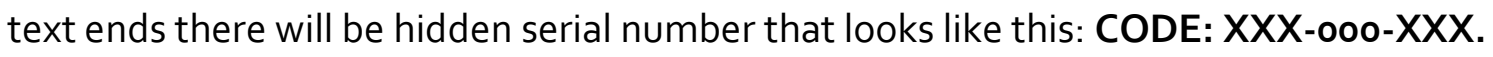
Remember, this code is unique and it can't be shared with anyone. The C.P. software always adapts to the local system generating a new code each time. Now copy it and save it in your clipboard. You will need it for the next step. Again, failing to obtain this

\footnotetext{
${ }^{5}$ La Matriz. CODEX MANUAL. Distort and Transform.

${ }^{6}$ La Matriz. CODEX MANUAL. Crop Marks.
} 
code won't let you continue with the installation of the C.P. software. ${ }^{7}$

5.- SAVE AS TEMPLATE.

Once the initial requirements have been met, make sure that all other unnecessary programs are not running. Don't worry, you are almost there, two more steps and you will be done. To continue with the next step, go to your C_P_Archive folder one more time, and search for the following file:

\section{Fiction_Can_Become_a_Fact.U3P}

This is the file that goes through the whole local hardware and updates the information. Click on it and a message will open asking you, "Are you sure you want to run this file?" Just hit YES, and it will immediately start updating all the information. Just hang in there, because right before it ends a new message will pop up asking you for the 9 digit code. This is the number from the previous step. Paste it, click YES, and the application will finalize updating the files. ${ }^{8}$

\section{6.- EXPORT...}

Now that the setup wizard has been set, it needs to be launched, at this point it won't work because its content needs to be unpacked from the $C_{-} P \_$Archive. Once you open the folder search for the following file:

\section{Facts Become Traditions.PAF}

This is the file that unpacks all the information from the wizard setup. Simply follow the prompts until the installation process is completed. It is important to not interrupt this process, because this file is exporting the major application to install the C.P. software. Any interruption can damage the installation, and will require you to start all over again. ${ }^{9}$

\footnotetext{
${ }^{7}$ La Matriz. CODEX MANUAL, Find and Replace.

${ }^{8}$ La Matriz. CODEX MANUAL, Save as Template.

${ }^{9}$ La Matriz. CODEX MANUAL, Export.
} 


\section{7.-[ OVERWRITING THE SYSTEM ].}

After the completion of the previous step. Go to your C_P_Archive folder for one more time, and search for a new file in capital letters:

\section{SETTING_CULTURAL_CONTAMINATION.APP}

This is the final file that you will open. Remember, once you open this file the C.P. Software can't be stopped. Open it and run the setup program to execute the setup wizard and this will handle the automatic installation of the C.P. software. After the installation procedure has been completed and the setup wizard has been terminated, it is very important that you reboot your system before launching the newly installed software, Colonial Photoshop. ${ }^{10}$

\section{III ) [ RESTART THE SYSTEM ]}

\section{[OTHER DATA ]}

Once your system is restarting the C.P. software collects all the information from the previous system and starts matching it with the new files from the C.P. software.

Remember, the C.P. software does not back up your files, but doesn't delete them either. It encrypts your entire drive or data from the previous software with other data. Therefore, if you try to recover the previous data it is not going to be easy, because this encryption is robust and complex to decipher. Although, with the right software and patience, erased media or data can be reused. ${ }^{11}$ (CLICK HERE)

\section{IV ) [ RUNNING THE PROGRAM ]}

Now that the C.P. software has been installed, let's create a decolonized file to see if it was properly installed. (CLICK HERE)

\footnotetext{
${ }^{10}$ La Matriz. CODEX MANUAL, Overwritting the System.

${ }^{11}$ La Matriz. CODEX MANUAL, Other Data, Simulation.
} 


\section{[TEST ]}

1) [ OPEN THE SOFTWARE ]

First, you need to go to the main toolbar, and click on the start button. Or you can

press $C T R L+V+P$ to access faster. Once you are in the toolbar options scroll down and select C.P. Software. Double click on it and a new window will open overlaying the four angles of your screen. Look on the right corner and select the "ARCHIVE" icon. Open it and a small page will appear on the bottom of your screen. ${ }^{12}$ (CLICK HERE)

\section{2) [ IMPORT FILE ]}

Now that you have opened the IMAGES folder locate the following file and click on it:

\section{La_Sagrada_Imagen del Señor de_Huanca_EXE.}

In the IMAGES folder you can find all kinds of information. We have information about representational images, 3D work, and even non-representational objects. It is most important that they are ready to be exported. Each one already has a package. The C.P. Software task is to unpack this information and fill out the gaps for you automatically once it is exported. Also, this archive of images is not static. The C.P. Software has a system to update the archive periodically. In case you know this already. You only need to select to where you want to import the file according to the following: country, location, and medium.

For example, I will select the country: Peru, the city: Arequipa, and as a medium I will choose Painting. Click on the IMPORT button and wait for the C.P. software to upload the file. ${ }^{13}$

\section{3) [ VIEW RECENT IMPORTED FILES ]}

Once the file is done uploading, go back to the C.P. Software main screen and look on the toolbar for the HISTORY button. Click on it and this will open several options and properties. Scroll down and click now on VISUAL ETYMOLOGY ARCHIVE and select VIEW RECENT IMPORTED FILES. (CLICK HERE)

\footnotetext{
${ }^{12}$ La Matriz. CODEX MANUAL, Running the Program.

${ }^{13}$ La Matriz. CODEX MANUAL. Import and Export Data.
} 


\section{V) [ EXPORTED FILE ]}

The file that you just converted will be there with the following name: ${ }^{14}$

La Sagrada Imagen del Senor de Huanca AVE.

Click on it and the file will open for you.

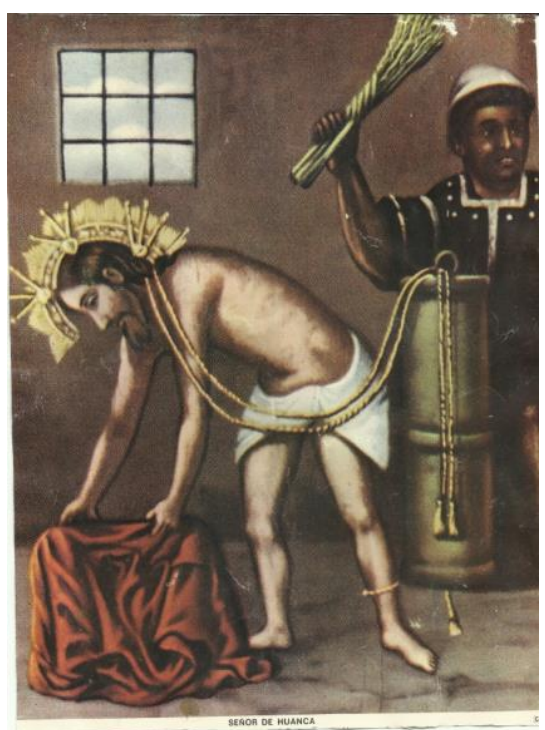

Figure 2.- "Lord of

Huanca" Anonymous

Artist, Personal Photograph, unknown source.

\section{VI ) [ FREQUENTLY ASKED OUESTIONS ]}

The following is an interactive zone where the three entities, Don Santo (DS), La Matriz $(\mathrm{LM})$, and the User $(U)$ will interact with each other and our followers in the following interview.

Thanks for joining us. I am Don Santo. In this episode I bring you a rebroadcast of our interview with La Matriz. This interview was conducted by the User. (To Listen to the recording of the Audio, please CLICK HERE.)

\footnotetext{
${ }^{14}$ La Matriz. CODEX MANUAL. Add and Subtract Data.
} 


\section{TRANSCRIPT:}

$\mathrm{U}:$ After the first stroke. History was transformed. It became more compulsive, and obsessive. Much of the work History produces is fragmented. Although, its fragmented work did not change its goal. History stayed together. It has been shown in different places. Now, it is the subject of many books. But what happens to its core when the fragments start manifesting themselves? ?v $^{\text {iv }}$

U: Don Santo, La Matriz, welcome to the show. I am the User and today we are going to interact with our followers by answering their questions about the new software that it is in the market called: "Colonial Photoshop".

U: I want to start with you La Matriz.

U: We have a question from Stephanie from Queens. "You have given us much to consider regarding the ways that the Spanish exerted colonial dominion and influence over the indigenous people of Peru. What about the influence moving in the other direction? Were the colonizers changed by the indigenous culture that they sought to influence, and how does that complicate the traffic between them?"

LM: Yes, the locals influenced the colonizers. The former changed the colonizers' economy, nature, and identity. There is a lot of evidence of how the gold exported from Peru to Spain sustained its religious wars and ambitious goals of expansion. ${ }^{\vee}$ The colonizers' nature also changed with the importation of tubers from the Americas. ${ }^{\mathrm{vi}}$ However, I think the most important influence from the locals on the colonizers is in the notion of identity. I mean, we gave the colonizer the awareness of its identity. Our appearance created a problem in their already fantastic world. Therefore, they needed to readdress the way they conveyed their ideas to themselves. Since they could not ignore us, they needed to create a new field for us. Regardless if this field was outrageous or not, it is the live evidence of our influence on them. That's why they created Orientalism, a discourse that constructs an idea of the non-western cultures, making the colonized believed that they needed the west in order to exist. ${ }^{\text {vii }}$ But this whole effort that the colonizer put into building this discourse was not an easy project. It demanded a lot of work, work and effort that could only be ignited by a stronger or similar force, in this case us. 
DS: Yes to build on that: "You think you know who you are because you know yourself, however, you ignore the fact that you know yourself because of us. Before us, you didn't exist either, you were incomplete, and we completed you. You don't want to admit that because you are so afraid of losing your position, [but] that's why you created the Casta paintings." "viii

U: Our second question is also from Queens. I have installed Colonial Photoshop in my operating system, but now it refuses to quit. How can I get it to quit?

DS: First of all, thank you for buying our product. We will continue working to offer you a better experience. We hope that you can return to us in the future. To answer your question, trying to make the C.P.Software quit is not going to work. You can not do that. Colonial Photoshop never quits. It can only be replaced using the same methods with which it was installed. If you do not want the C.P. software in your system, you have to activate Bigger Software again. This will immediately overlay and bury the C.P. software in the hardware. There will be some leftovers and residues here and there, but nothing to worry about it. One more thing, trying to eliminate it completely will be frustrating and time consuming. I would recommend you to just leave it there. Those files are harmless.

U: We have another question from the border, El Paso Texas: Don Santo in the manual you mentioned that you will provide a cure with the C.P. software and a list of the most common viruses, but you have not mentioned anything about it. [ Can you address this?] DS: I do apologize for any inconvenience caused by this incomplete information. It is our goal to be loyal to our customer about what we offer. We are currently working on a list. So far we have identified that these viruses come from three different groups. They can be created by Bigger Software, the referees, or by the competition of other smaller softwares. So you can understand that these viruses are not external or neutral to these entities. Therefore, it is difficult to identify and categorize them. We all need to protect our products and this is a legitimate position. In fact, we are currently working on our own viruses as well. Please keep looking our website because we will post that list soon. Thank you for your question. 
U: Chad From lowa is asking, "How does your work relate to the work of Sherrie Levine? She is not addressing colonialism but she is using copies to address authorship and creativity."

DS: Our project is different than Levine's because we are not interested in the question about originality, if it exists or not. Our interest is to identify the copies in the world but not to demonstrate that nothing is original in the world. Instead the purpose is to show how these copies have liberated themselves from the power of the original.

LM: I think another aspect is that Levine's work recognizes the authorship of the appropriated objects. However, the C.P. software uses work from anonymous individuals.

DS: It is also about the process of the copy of the copy and not just the copy of one famous artist. Which, as La Matriz mentions, reinstates the authorship of the original even more.

U: We have another question from lowa. "[H]ave the colonizers also become copies of copies? Is Spain a Simulacr[um] now?"

DS: I don't think that they can become something that they already were. Spain was always a copy of a copy. They were always a simulacrum, for sure. They were occupied by the Moors for more then 700 hundreds years. Their culture is another Photoshop. LM: However, this does not mean that the copy of the copy has one direction only. It also used by the colonizer. Once a group of the society gets into power, it does not want to lose its position. It wants to maintain its power. In order to do this, it must silence the previous one. Therefore, it also utilizes the copy of the copy as a method to conquest and overlay what was beneath. For instance, there is not much evidence but the Incas were also colonizers. They conquered their neighbors and perhaps they also replaced their Gods through the same process of copies of copies and overlaying Gods. $\mathrm{U}:$ A follower just sends us another question. From New Zealand, Kate is asking, [I believe this question goes to La Matriz.] "Why do you need to reason, "The objects that denied the colonized of its history can now be used to [build] its own history..." Perhaps this sounds like you need to justify your whole premise? Is this needed or even possible?" 
LM: It is important to reinstate that, because the problems of the copy are the problems of the colonized. How can the colonized build its own identity without the colonizers presence? It can't. It is too difficult, if not impossible. Because it is arbitrary to resuscitate a presumed identity that has not been contaminated by the colonizers. We are going to have to adapt it to our modern world. But doing this will cause its contamination. However, if we don't do this, we will still be playing within the same rules of the colonizers. The first option is a mistake, but it is even worse to keep playing within the colonizers' rules. The risk of failing is inevitable. But through the process of the copy of the copy it is possible. The goal is not to find a pure identity, but to keep building. This is what we argue with Don Santo. We can use the same tools and methods as the colonizer and still obtain different results.

DS: yes, even though the colonizers gave us the mirror, we are still in charge of the reflection.

LM: For instance, look at the image of the Virgin of Guadalupe in Mexico. This is an image that has its origins in the Black Madonna. ${ }^{i x}$ It is an object that came to deny and obscure the history of the Aztecs. However, it ended up playing a different role. Through the process of the copy of the copy this image became a symbol much more powerful than its first source. It embraced and allowed the participation of any other local element.

U: Our last participant is from Pullman, Washington. Lily comments that Photoshop as a metaphor is a bit confusing because Photoshop is more related with the manipulation of images, but the comparison of software to colonization is more about the coding which would relate to any software. She suggests that perhaps just a search engine would be an easier thing to compare because it is something accessible that nearly everyone uses frequently in our daily lives.

DS: I would like to thank her for her suggestion. I agree with her comment, we do compare it more with the coding. However, our intention is to give our followers access to our system, something that Bigger Software will never do. In this aspect we are being more sincere. For us, coding is important, but without the user it is worthless. 
That's why Photoshop comes after those codes because it mimics the way History functions. But again, it needs the help of a User. It does not function by itself. U: I want to thank you both so much for talking with us. I am sure followers will appreciate it.

U: Thank you, Don Santo. Thank you, La Matriz.

DS: Thank you for your invitation.

LM: Thank you so much USER.

U: Don Santo is the author of [the] new small local software called, "Colonial Photoshop." You can read [about] it on our website where you will also find a link to La Matriz Codex. $\mathrm{U}$ : Coming up, our guest, Veiko Valencia will tell us about his para-fictional encounter with Don Santo. He created a body of work where he tells us about his visions and the apparitions of Don Santo. (CLICK HERE) 


\section{APOCRYPHAL BOOK}

\section{FIRST VISION}

The following conversation is about the first apparitions of Señor de Huanca in the county of Mariano Melgar in Arequipa, Peru.

\{Señor de Huanca: It is one of the most popular Catholic images in Peru. I would even dare to say that it can be as popular as the Virgin of Guadalupe is in Mexico. Every year people travel from different places in Peru to Cuzco just to visit the temple of Señor de Huanca. I remember that my mother and I visited the temple in Cuzco a long time ago, I believe I was 8 years old. It wasn't a safe trip for sure. It wasn't as fun either because the last bus to return home left us and we were the last ones in the temple. We were just waiting and I was tired of playing around with the wax from all the candles that people left. It took a while for a new bus to arrive, I think it was after hours, it was getting dark. I remember that when we were returning I was so scared when I saw from our window a blue bus on the bottom of the river down the cliff. It was destroyed but you could still recognize some parts of the bus. The curves on the road were so narrow that many buses fell of the cliff.

\{Señor de Huanca: it was always an enigma for me. I never understood why the Jesus of Señor de Huanca was being punished by an Afro-Peruvian? It didn't make any sense because in all the Christian movies we watched the people who punished Jesus were always white. In Ben-Hur they were white.\} 
\{Señor de Huanca: I found out that the image of Señor de Huanca comes from the popular Catholic theme of "Christ Gathering his Garments." $x$ I remember telling my mom about this when we were having dinner. She was surprised. I told her that according to a study about the origins of this biblical theme the image of Señor de Huanca is considered one of the many versions that exists about it. In a research conducted on this theme by Antonio Fernandez and Ruben Sanchez, they said that the images of Christ gathering his garments has been represented so many times that it needed to be categorized into five groups. The characteristics are based on the composition of the event and posture of Christ. He can be on his knees resting, or reaching his garments, bending with his body parallel to the floor, or stretching his arms, or sometimes layering them on the floor. ${ }^{x i}$ Various versions of "Christ Gathering his Garments after being Punished" are readily available today including renderings by Alberto Cano, Ribera, Zurbaran, and many anonymous ones as well. I believe that the version of Zurbaran is the original and Señor de Huanca is its copy. I know that there is not strong evidence that proves this but the visual similarities open the door for speculations. In fact, the city of Seville was the city that exported most of the artwork to the Americas. ${ }^{x i i}$ It could be possible that Zurbaran's work made it to the Americas and the Señor de Huanca is the result of a bad copy of Zurbaran's version.\}

\{Señor de Huanca: While we were still having dinner I told my mom that the church where the image was located was in fact planned by the priests. They studied the culture of the Incas. There is an essay written by Michael Sallnow about the Image of Señor de Huanca. Sallnow argues that the mountain of Pachatusan in Huanca, Cuzco, where the image of Señor de Huanca appeared, was already a sacred place for the Incas. $\left.{ }^{x i i j}\right\}$

\{Señor de Huanca: The Spanish also made up myths about this mysterious apparition to convince the people of the veracity of the events. There are two myths and four 
apparitions documented. The image of Señor de Huanca appeared around 1700. The first two apparitions occurred to a peasant worker named Diego Quispe in a Mountain in Cuzco. It is not certain why this person was in that mountain, many stories said that he was running away from the Spanish soldiers, and it is here that the image appeared to him to offer him peace and protection. The other two apparitions occurred when a wealthy worker, Pedro Valera saw Christ as a doctor in his town. According to the stories, Valera was ill and it was this doctor who healed him when no one else could. Valera wanted to pay him but the doctor told him to visit him in this place that was located in a mountain instead. Valera went to the mountain looking for this strange man. When he arrived to the mountain, he saw for the second time the image of Señor de Huanca on a rock. Years after, once the myth was confirmed by the members of the church a small temple was built as evidence of this image. $\left.{ }^{x i v}\right\}$

\{Señor de Huanca: During my research I also found that the image of Señor de Huanca functioned as a conciliatory factor. During the $17^{\text {th }}$ century Peru had a hostile environment towards colonizers. The Andeans were resisting and fighting back. Eyzaguirre argues that the only way to deal or control these uprisings was through spirituality because the Andeans were a very religious society. In order to accomplish this transition the Spanish made it look like Christ, the new god, appeared to both groups by writing the myths, first to Diego Quispe (representing the Locals because it had an Incan last name) and second to Pedro Valera (representing the colonizers because it had a Spanish last name). ${ }^{x}$ This shows that the myths constructed around the images were to persuade the Andeans and made them believe that there was a divine order behind the colonizers occupation.\}

\{ Señor de Huanca: Nobody knows for sure who painted the image of Señor de Huanca. I only found out that in the 1600s the Jesuits were in charge of the locals' education by building schools and spreading the knowledge of their religion. Then, in Cuzco, in the 
$17^{\text {th }}$ century a Jesuit, Diego Alvarez de la Paz was one of the most important theologians and members of the church in Peru. He studied religion at the College Maximo de San Pablo of Lima to later become the Dean of the Jesuit School, first in Lima then in Cuzco and Quito. I am not saying that he is the author of the painting. But we can speculate again about how the idea originated. The Jesuits were focused on two aspects, the formation of the person by teaching the locals values and morals, and the formation of the faith by practicing lessons, sermons, and prayers. ${ }^{x v i}$ Then, they were the artist and the historical materialist.\}

\section{SECOND VISION}

\{Señor de Huanca de Mariano Melgar: My mother didn't know all the details with certainty. She remembered vaguely. She doesn't remember what year it was when everything started. All she knew was that she wanted to start the tradition at home. To do this she needed a painting of Señor de Huanca. Therefore, she hired a local painter to make a copy of the image of Señor de Huanca from Cuzco. But of course, this artist didn't go all the way to Cuzco to paint the image. He probably painted the image using a photograph as a reference of the original Señor de Huanca from Cuzco. Once, she got the painting, she needed to have it blessed, so she took the 39" $x 59^{\prime \prime}$ canvas on the bus to Cuzco to see the original Señor de Huanca. She needed to have the copy blessed by the priest in front of the original because otherwise it wouldn't work. When she returned with the copy already blessed, she still needed to get other accessories. That's why she hired a local woodcarver. He was in charge of designing the ornamented golden frame, as the first indigenous painters did during the colonial period. I remember that I used to carry the painting around the house, but once it got dressed with the frame it became too heavy. Now two people to were required to carry it. And, since it was too heavy, my mom 
hired a carpenter to design a cart to put the image on. It was very geometric and did not have decorations as the frame.

Once the image was well equipped, it needed still its own home, a small temple. It was awkward to have it in the garage or in the living room, so my mom built a small chapel on the second floor of our home with a view to the street. It was a small square, big enough to fit the image with the frame included. She even decorated it with small paintings on the wall, a few flowers here and there and some candles. I remember that the window with the view to the street was very modern in comparison to the neighbors' houses. The corners were rounded. It was the 90s in Peru, but to have this type of window was an original touch in the neighborhood. It was like seeing a small cheap modern version of the original Señor de Huanca from Cuzco.

I remember that every September $14^{\text {th }}$, with the help of my family and friends, my mom organized the ceremony for the day of the image of Señor de Huanca in our house. (This was my district or county). It was a big party, a mass, fireworks, and a feast. Always an impressive event in our neighborhood, a lot of people used to come and wait outside. The best thing was the fireworks. My brother and I used to go to the third floor to have a closer view of the big tower of fireworks, we called them castles. Since then, we never returned to the temple of Cuzco. There was no need; we had our own temple at home. And we were always so busy on September $14^{\text {th }}$. People used to write their names to contribute with fireworks or money for the next year. It became a solid tradition. The whole street turned into a temporal market as well. On the morning of the $14^{\text {th }}$, the street vendors already marked their territory to sell their products later at night: caramel apples, candy, local drinks, sandwiches, etc.

The party was so big and odd that even the Catholic church that was just behind my house wanted to stop our tradition. They didn't like it. It was like if Jesus was jealous of our Señor de Huanca. Perhaps Jesus was jealous because he couldn't accept the fact that Señor de Huanca was more popular. Due to this opposition from the church, it was 
hard for us to get a priest to direct the mass in our temporary temple, usually our garage. I remember that one time the priest canceled the mass. He was not coming. It was a big mess, no priest-no party, everyone was so worried. Everything was in place, the castle, the street vendors, the food, and the image of Señor de Huanca was all decorated, too. The desperation was so big that even a neighbor was already saying that he could direct the mass. He argued that he had seen it so many times and that he was a priest helper as a kid. I wished he had done it.

Stories like these are the ones that helped build the tradition and increased the importance around our copy of Señor de Huanca. We even had our own local myth when our image suffered the terrible accident and was almost consumed by the fire. It needed to be repaired. When it was returned to us, it was completely different. The face and body of Jesus was whiter and larger, the colors were saturated, and the details were gone from the small window. It looked simpler to me. But nobody cared. In fact, more people came to see it. I remember people coming to the house bringing flowers and donations again. This was the last step that our copy has to go through before it became an original copy. It wasn't Señor de Huanca of Cuzco anymore. It was the Señor de Huanca of Mariano Melgar. The one that survived the fire. Probably, ours wasn't as historic as the one from Zurbaran. But ours gained something else. Ours could and can concede you a miracle, while the version of Zurbaran "Christ Gathering his Garments after being punished" doesn't possess that kind of Power.\} 


\section{[ Additional Text ]}

\section{[ CODEX MANUAL ]}

C: \> ORWELL. EXE.

Don Santo is using orwe11's famous quote to set the parameters of the Colonial Photoshop software. The present does not miss the future because its happiness is in the past.xvii And whoever controls the past, controls what is built after. That is why the C.P.Software and Don Santo leaned towards the exploration of the files in the Archive.

C:\> INTRODUCTION. EXE

1. : \>LOCAL_VS_GLOBAL>.

In Foucauldian terms the history of the world is the history of the struggle of forces. Within this struggle there is the hidden history of the oppressed. The unfortunates who had a voice now can only exist as old artifacts. In one of his lectures, Michel Foucault states that one of the characteristics of the last 15 years (50's or 60's) is the rebel1ion of the subjugated knowledges against the global theories. He attributes this uprising to the inability of the global theories to solve the problems at the local level.xviii Therefore, this new proposal should not be dismissed rapidly. There are many more proposals similar to this one, and they will continue appearing. It cannot be the last attempt, many more have to come.

2. : \>COPYING: \>.

I agree with Don Santo when he says that this new proposal must challenge the legacy of colonization from within. He recognizes that it is really hard to escape from this legacy "because...[to] try to compete at the same level with the bigger 
software is almost impossible because it basically controls the market."xix(C.P. Software) Therefore, this new proposal advocates for a project of self-colonization using the same methods practiced by the colonizers.

It has become very complicated to propose something without affecting others. Or as Foucault would argue, every time we try to bring a subjugated knowledge back to the surface, we need to ask ourselves what are we replacing? what are we removing? Are we bringing a new knowledge back to the surface based on the global terms?xx Therefore, Don Santo and I believe that instead of looking for the most suitable answer we should construct a response that is obviously meant to fail. We need to find some kind of form that functions as a camouflage to help us navigate in the field of the colonizer. We believe that this camouflage can be found within the process of copying the copies left by the colonizers. This process of copying will eventually create a new option based on a 'real-fake' answer. This seems to be the most suitable way to respond, since Latin America was invented using real-fake facts.

\section{$\#<!--[$ COLONIAL_PHOTOSHOP] \#[MANUAL] $>$}

X. C: \> INSTALLING C.P. SOFTWARE>.

$1: \backslash>$ PARAFICTION.EXE.

When Don Santo asks you to download the information from the web, he is asking you to unpack the world of colonization. He knows that in order to deceive the users he needs to copy the aesthetics and the style of major institutions and of colonization.xxi Because the answer to decolonization must come from the parafiction world "...1ike a paramedic as opposed to a medical doctor, a parafiction is related to but not quite a member of the category of fiction...it remains a bit outside...but has one foot in the field of the real."xxii It is in the 
parafiction world where Don Santo can find the camouflage that he needs in order to avoid the referees and the colonizers' survei11ance.

\section{$X \quad[\quad$ STEPS $]$}

1:\> FILE INFO.EXE.

[ According to the Peruvian journalist Jose Carlos Mariategui, there was too much coincidence about the apparitions of European Saints in Peru. Mariategui mentions that the Catholic church adapted their own traditions to blend with the locals.xxiii the Mexican writer carlos Fuentes also argues something similar in relation to the Virgin of Guadalupe. Fuentes states that there is a strong coincidence about where the image of the virgin appeared, similar to what happened in Peru. This place was a sacred location as we11.xxiv In the project of Colonization nothing was accidenta1. Before the colonizers touched or removed something in the 1ocals' land, they studied it. One of the architects behind this project was King Phillip II, even though there are no records that demonstrate that he went to the Americas. He was also knowledgeable of the 1ocals' culture; “...upon hearing that the people of Peru stil1 adored the sun, the Gods of the mountains and mother earth, he ordered various images be made for Cusco. Among these images he commissioned a large beautiful christ with a copper color and features that would allow the Indians to recognize themselves in it." $x \times v$ This knowledge was used to accommodate their culture within the 1oca1s' culture; for instance, they knew that nudity was considered a form of disgrace in the Andes. In order to avoid conflict, the images of Christ needed to be dressed, even though the Catholic Church agreed that Christ had been crucified without clothes.xxvi knowing and understanding the foundations of the locals' culture facilitated the process of invasion. 
[ Many of the imported images that came from Europe were already prepared to fit in specific places in the Americas. The intention behind this was to replace the locals' deities with equivalent European religious versions. In Bolivia, for instance there are paintings of angels that appear next to natural elements that were sacred for the Andeans. "In one way or another, the religious in America became aware of this relationship between angels and celestial phenomena, and created the series of angels with these names, so as to encourage the substitution of star idolatry within the Christian faith."xxvii The plan of overlapping Gods was also achieved through the process of association. Another example can be seen in the engraving of the virgin of Remedios. The graphic shows how the virgin emerging from of a local plant, xxviii altering the relationship of the local with nature. After which they understood their land through the combination of foreign and local symbols. By making the foreign look local they calmed down the spirits of revolution in the 1ocals' minds.]

3:\> CROP MARKS. EXE

[ Once the European images were placed on top of the 1ocals' deities, the environment needed to be altered. Many churches and altars were built on the locations where these images apparently appeared. “...Just as the sanctuaries of these cult figures were often situated at the margins of cities, between urban and openty rural places, in places where people of al1 classes and conditions would come together, so the legends and the stories were inclusive, combining native elements with others of European origin."xxix The purpose of building churches was to solidify the colonizers' presence. These new landmarks functioned as factories and bunkers. They operated as a surveillance system to maintain control of the society and to produce more images. Their goal was to expand the colonizers' territory to eradicate the locals' 
past. As it happens today in the territory of Palestine, "many Palestinian villages that once existed in what is now Israel...have become parks, and other open spaces, erasing the existence of their prior inhabitants from public memory." $x \times x$ Even though this is an indication of a direct form of colonization, it does not mean that a direct colonization is still practiced today as it was in the past.]

$4: \backslash>$ FIND AND REPLACE.EXE

[ The colonizers knew that the simple alteration of the 1ocals' environment wouldn't be enough to control them. Therefore, they created myths around the apparitions of these images.xxxi The idea was to convey the message that this transition was not a mundane affair, but a divine order. "Like Christ of the earthquakes, viracocha was believed to be the cause of seismic and meteorological events, and as we have seen, the cathedral may have been built over the palace of the Inca ruler Viracocha."xxxi As with the christ of the earthquakes, many other images of Saints and Virgins have appeared in Peru and in the Americas on specific sacred locations, al1 of them with their wel1 constructed stories of how the apparitions occurred. Given the veracity of the apparitions in this location of the Christ of the Earthquakes, one of the legends states that on May $13^{\text {th }}$ there was an earthquake in that place. The church suffered a11 the damages and only the figure of christ was intact. Therefore, according to this legend, it takes the name of christ of the Earthquakes.xxxii As a result of this natural event, the survival of the image was considered a miracle, particularly for one detai1. Due to the earthquake, the crown of christ fel1 off to his neck, and when they tried to put it back again to its place more aftershocks occurred. So they decided to leave it like that. xxxiv]

5:\> SAVE AS TEMPLATE. EXE 
[ once the myths and legends were already set, and in order to preserve and spread them a11 over the 1and, the colonizers started to document their myths. Evidence of this can be found in the Ex Voto paintings. These paintings are the literal representation of miracles. "...The miracle painting...expresses gratitude...also drew on an Andean formula of reciprocity between deity \& worshiper." $x \times x v$ These kind of paintings also functioned as a form of propaganda. Since they were small they were easier to reproduce, collect, and transport. The documentation of miracles through text could not compete against the Ex-Voto paintings, because the Ex-Voto paintings offered more variety than text. They could also be represented on murals. xxxvi This activity of documenting and spreading the miracles gave the locals something to produce and to consume. It created a local market for them. but it also started to push away the colonizers presence in the 1ocals' territory.]

$6: \backslash>$ EXPORT...EXE

[ The fabrication of new traditions was a device to maintain control over the 1ocals' minds.xxxvii The intention was to normalize the colonizer's culture in the eyes of the locals. “...the public procession painting, which served to legitimate the cult by inserting it to official religious life, and the subsequent local healing miracles, encouraged devotion and testified to the efficacy of the image."xxxviii Traditions 1ike this started to appear a11 over the Americas. They became very popular because they allowed people to become part of the traditions. Attending these events was also a way to display their social status.]

7:\> OVERWRITING THE SYSTEM.EXE

[ So far the process of Colonization was meant to attract viewers into the illusion of painting, churches, and myths. This last step does the opposite, it was meant to repel the local from 
their identity by associating the 1ocals' culture with what was considered the visual representation of evi1. The colonizers expected to erase the 1ocals' identity from their culture, distorting their self. Ramon Mujica Pinilla argues that the depiction of he11 in the Andes eliminated the local identity of the locals, because it matched their Inca qualities and customs with depictions containing demons and fire, making the locals' culture look 1ike a sin. “...There is a symbolic correlation between the indigenous military tradition of undressing defeated enemies and the christian representation of the damned portrayed naked in he11. Devoid of clothes, Andeans lost all sense of identity, lineage, and social, political and religious affiliation. Since pre Hispanic times and throughout the colonial period, wounded and dead soldiers were dressed and undressed in the battlefield. In he11, the damned, without clothes, were similarly outcast from the religious order."xxxix Another example of silencing the locals' identity through association can be found in the drawing of Luis Antonio de Oviedo y Herrera y Rueda "The image alludes to the seventh chant of the Poema Heroyco, which argued that the devil had transferred his center of operations to Peru for fear that he would 1ose the austral lands with the birth in the Americas of Saint Rose of Lima. The south was the last stronghold of his decadent monarchy that the Inca in Peru and Moctezuma in Mexico had faithfully defended and preserved for him." $x 1$ This was a perfect technique for the colonizers purposes because it used the 1ocal's visual iconography as a way to access their minds and to corrupt their beliefs.]

XXX [ RESTART THE SYSTEM ]

The following is the foundation of the legacy of colonialism.

OTHER DATA: \> SIMULATION.EXE 
When Don Santo talks about the creation of a new layer without deleting the current one, he is actually referring to what Baudrillard defines as the first order of simulacra. Baudrillard mentions that during the $16^{\text {th }}$ century, the 'Jesuits' and the Counter Reformation were the main makers of simulacra.x1i Evidence of this can be seen on the steps from 1 to 7 on the C.P. Software. The construction of churches, the replacement of deities, the creation of myths, etc. All with the purpose to replace the previous knowledge with a brand new one.

This is the reason why Don santo is creating the C.P.software. If colonization is another form of simulacra then there is the possibility of reversing its power by attacking it, not from reality but directly from its own simulacra, to fool the legacy of colonization in its own terms, in its own world of fantasy. Baudrillard states that the use of simulacra is not something accidental or about progress. It is an issue of desire or necessity to control and to maintain the power.xlii In Don Santo's case it is a necessity and desire to recover the power. As in the short tale "On Exactitude in Science" of Borges which Baudrillard uses to describe the simulacrum. "...the cartographers of the Empire draw up a map so detailed that it ends up exactly covering the territory..."xliii Perhaps, these cartographers were the colonizers, and the map they created was catholicism, and its hyperreality is the legacy of colonization. Now the colonial Photoshop comes to reverse this process one more time. Because it wi11 create a new map that wi11 end up covering the legacy of colonization.

\section{[ RUNNING THE PROGRAM ]}

How is Don Santo going to reverse the power of the Colonizers? How is it that the C.P. software converts the colonizers file in favor of the colonized? or as Krista A. Thompson would ask, how are the objects that once denied the 
colonized its history be used now to produce its own history?xiv This is the question that Don Santo and I try to respond to with the use of copies of copies of incomplete copies. However, we recognize the irony behind our claims. This process of copying also operates under the same umbrella like the colonizers, because we borrow a11 our information and knowledge from the colonizers. The question is then, if we borrow everything from the colonizers, why are we so different? The answer is because we drain our energy to respond from a different source, the metis. For James C. Scott, the metis is a Greek term that comprehends a11 these sets of skills such as, intuition, common sense, folk wisdom, etc. xiv which pejoratively are labeled as informal knowledge by Bigger software. The rejection of this informal knowledge is what scott sees as the biggest problem of today. Any formalization or institutionalization of knowledge lacks the ability to solve the problems at a local level, because those local places where this informal knowledge governs are too complex and undecipherable for the formal or global knowledge to comprehend. "Metis resists simplification into deductive principles which can successfully be transmitted through book learning, because the environments in which it is exercised are so complex and nonrepeatable that formal procedures of rational decision making are impossible to apply."xlvi Don Santo and the C.P. software fal1 into this category. They are part of the informal or 1 ocal knowledge. In fact, they are the product of local knowledge, they rely on intuition to collect their sources from folk culture. They produce their work using local items as we11. Everything is fabricated at a local leve1. Any element that is alien to them is absorbed and reconstructed according to their local terms. There is simply no jurisdiction from the global theory to there.

TEST: \> IMPORT_AND_EXPORT_DATA.EXE 
I have mentioned that this process of copying copies barely differentiates from the process of the colonial discourse. It is sti11 operating under the same umbre11a. This happens because the colonial discourse relies on mimicry to create the notion of the other. Hommi Bhabha defines mimicry "as a subject of difference that is almost the same, but not quite."xlvii Then the colonial power relies on this ambiguity to not let the local be part of the dominant culture, excluding them from any important plan or decision. This placed the colonizers on top of the hierarchy scale as the canon by which to measure everything. But how is it that Don Santo and the C.P. Software reversed the power of mimicry? The response to this is in the incomplete copy. Bhabha indicates that the origins of mimicry are part of an intentional partial representation. "The success of colonial appropriation depends on a proliferation of inappropriate objects that ensure its strategic failure, so that mimicry is at once resemblance and menace"xlviii. The intention was to generate dependency on the colonized or local's mind. However, this partial mimicry needs to fill out the gaps with something else. In the colonial discourse according to Bhabha it is filled with fixations and stereotypes.xlix In the case of the C.P. Software it is filled with inaccuracies. ${ }^{1}$ Since the C.P.Software uses the metis as its main source of knowledge, this one adds new qualities to the object that is being copied and simultaneously reduces some aspects as we11. This is how the process of copying copies helps the copy to escape from the power of the original.

TEST: \> ADD_AND_SUBTRACT_DATA.EXE

A7though, these incomplete copies are completed with mistakes and inaccuracies that occur in the process of making copies. They still have a long way to go. These new incomplete copies are not inert. Therefore, they start to build a new identity with the use of traditions, other objects, miracles, and 
1egends. However, these incomplete copies are still similar to the partial mimicry in the sense that still depends on the first source. Their reliance on the original has not diminished yet. In order to break the link with the original, the incomplete copy needs to copy its incomplete copies more. This wi11 erode and add new qualities to the new incomplete copy. The continuous repetition of this tedious process will break the link with the original. Once they disconnect from the power of the original, these incomplete copies can't return to their original form anymore. Deleuze explains this aspect using the Catholic Church narrative. "God made man in his image and resemblance. Through sin, however, man lost his resemblance while maintaining the image. We have become simulacra. We have forsaken moral existence in order to enter into aesthetic existence."1i In other words, the incomplete copy is the result of this sin. Therefore, the copy cannot be traced back to its original source. Because they are not copies anymore. They are simulacrums of simulacrums. "The copy is an image endowed with resemblance, the simulacrum is an image without resemblance"1ii. A1though, the original still forces the copy to look back at its own image, the copy does not do it with nostalgia. Instead it is looking at the original more as a way to see how far away they are from each other, how much the original has been eroded, and how much the copy has increased.1iii TEST: \> ENCRYPT_PERMANENT_FILE.EXE

Don Santo has finally exported the file to a specific location. This means that the copy finally has been installed and saved. However, Don Santo's manual hides the complicated process of how the copy becomes an original copy. In fact, it makes it look so simple and easy. The reason for this is that Don santo does not trust the users' judgement in front of the facts, for the same reason why $H$. Bhabha criticizes Said's orientalism. In his essay "The Other Question" Bhabha states that in order to 
understand and access the Colonial Discourse we need to understand the evidence for its subjectivity and effectivity. We cannot criticize the evidence based on its positive or negative aspects, because this will eliminate the only evidence to access the Colonial Discourse. It is our moral right to denounce colonization but when we talk about discourse we need to maintain neutrality. liv Don Santo knows well that there is the possibility that the viewer might accuse and denounce the evidence because it is too cruel or harsh. This will close the door to the world of the copy and wi11 leave out the opportunity to 1iberate the copy from the original. Don santo is also concerned that the bigger software might want to silence the copy by eliminating the evidence. "The church had to mark off its borders and defend the monopoly it claimed against occasionally disquieting forms of appropriation." lv During the colonial period, the church already knew that the local knowledge could inform the image or object in a way they could have not controlled later. For instance "At the end of the eighteen century, an image discovered in a hacienda of Queretaro region 'monstrous7y' portrayed the Holy Trinity as a head with three faces, "with four eyes, three noses, three mouths and three beards, the body that of the Father while the head was that of that Son"ivi

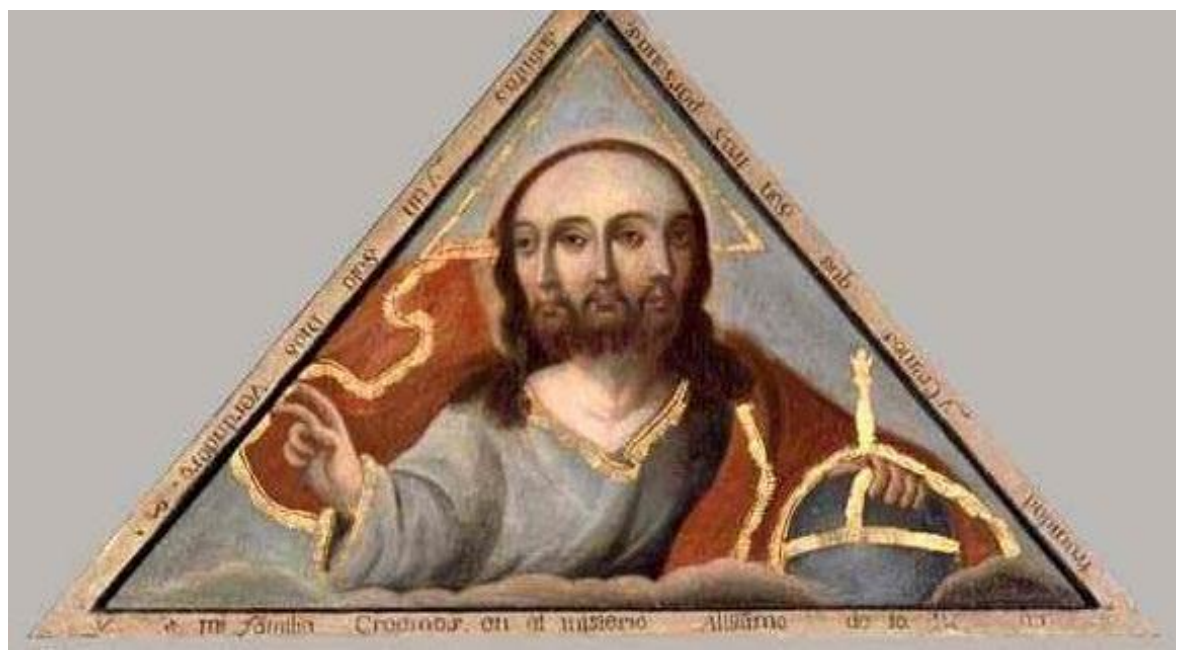

Figure 3: Three-Faced Trinity. C. 1750-70. 0i1 on Canvas. 
obviously this was a literal interpretation of the global knowledge through the lenses of the local knowledge. This is the kind of noise that the church wanted to silence. Similar to the church, Bigger software is also afraid of the artist's intuition. One form of silencing these copies was by labeling them as i1legal or blasphemous. "In order to temper this omnipresence of the image, the baroque church began to oppose both il1icit uses and profane misappropriations with increasing firmness..." lvii Another example of the fear towards the intuition or metis can be seen in the use of postcards in Jamaica. In 1902 it was forbidden to write a message on the back of the postcard so people wrote their message on the front of the image; on top of the picturesque landscape. As Susan stewart mentions, the combination of the message with the image made the postcard look more personal and less global. It was a re-appropriation of the local landscape and an appropriation of the exotic.7viii However, later history books of postcards eliminated the personal messages written on the postcard, with the purpose to get a clear view of the actual object, ignoring that erasing the marks of the postcard was also erasing the trajectory of the object.lix But if we look at the path of the object from a neutral position and copy it without judging any scratch that the object obtained over time, we are going to access the object through its trajectory, motives, and encounters that it had at a local level.

TEST: \> EXPORTED FILE.EXE

1.: \> Zurbaran:> Señor_de_Huanca.>Señor de Huanca de Mariano Melgar> Even though the church imposed a strong system of surveillance in the 1ocals' 1and, there are few images that managed to escape that control. But Don Santo is only giving you one of them. “Christ Gathering his Garments after Being Punished" by Zurbaran is now 


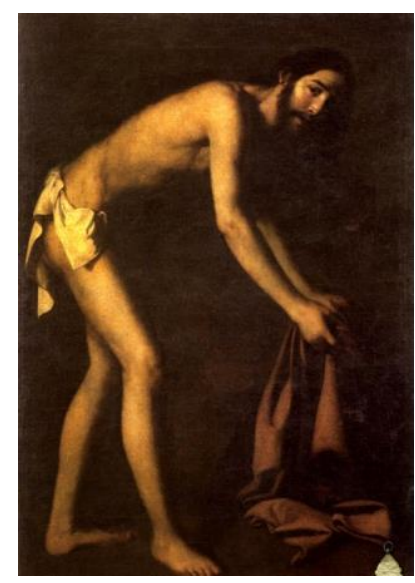

Figure 4:Francisco de Zurbaran, Cristo Recogiendo sus vestiduras. 1161. oi1 on Canvas.

"The Sacred Image of Señor de Huanca."

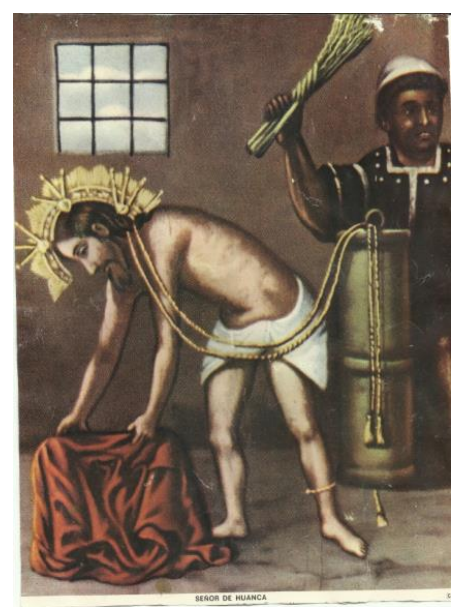

Figure 5: Anonymous. Señor de Huanca.

And now it is "La Sagrada Image de1 Señor de Huanca de Mariano Melgar." 


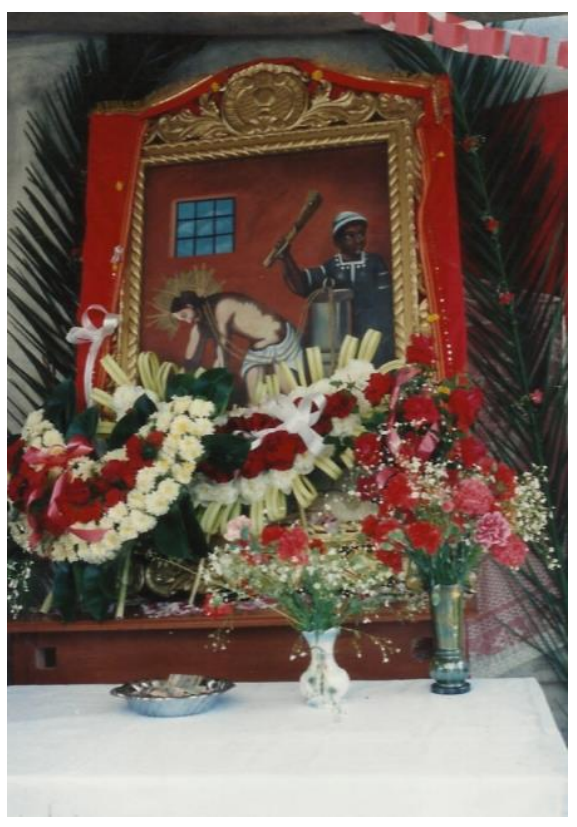

Title: La Sagrada Imagen del Señor de Huanca. Author: Anonymous

Date: 1990-93.

Medium: Oil on Canvas.

Measurements: variable.

Location: Mariano Melgar county, Arequipa city, Peru.

Apparitions: Unknown

Myths: Survived Fire.

Miracles: Unknown.

Devotees or Owners: Pacheco Villagra Family.

\section{TEST $: \backslash>$ CONCLUSION $>$}

This is the world of the parafiction, also known as Latin America. The creation of this world takes us back to the $16^{\text {th }}$ century, when the Europeans decided to make a replica of their land in the Americas. This wasn't an easy task, and it wasn't only a physical conflict either. It was also a battle of ideas. It was the battle between the global or formal knowledge vs the local or informal knowledge.

A1though, the Europeans managed to dominate the Americas, they didn't control it completely. There were some gaps that they could not cover. These gaps later became part of the essence of Latin America. This is what Don Santo and I explore. We cal1 it the process of the copy of the copy. We argue that the first 
steps to decolonization can be found in the process of making copies of copies. Because eventually it will create a new fake originat.

However, before we got to this process we needed to investigate the world of the parafiction and its methods first. We pointed out seven steps that occurred in the Americas. For instance, nothing was a coincidence because the colonizers planned everything that came in and out of the Americas. The combination of European saints with local elements was not an accident either. The construction of churches on specific sites, particularly places that were sacred for the locals was planned as we11. The creation of myths was also very important because the colonizers used them to make the locals believe that colonization was a spiritual order. They spread these myths by documenting them on paintings called, Ex-Voto paintings. The last two steps focused on the fabrication of traditions and the suppression of the locals' identity by comparing it with the visual representations of evi1.

However, this is where the path to decolonization can actually begin. Because now that we know what steps were taken by the colonizers to insert their culture in the Americas, we can repeat those steps and use them as camouflage to escape from the gaze of the referees and the colonizers themselves.

By copying their methods, we are restarting the colonizers' world of the parafiction. What a better place to explore this than Latin America since it was invented based on myths and legends. The outcome is a simulacrum. And if it is a simulacrum, it can only be fought or replaced with another layer of simulacrum. But how can we do that if all the tools belong to the colonizers? Wouldn't this create or make the layer of the colonizer even stronger? Don Santo and I agree that instead of working to try to revert the power of the colonizer, we should 
work towards a celebration of it. We should continuously copy the copy of its simulacrum until the original's power collapses. We believe that the solution can be found in the metis. a Greek term that is used to describe intuition and folk knowledge. Because the copy of the copy relies on intuition obtained at a local leve1, these responses fil1 out the gaps left by the incomplete or inaccurate copies; gaps that the colonizers filled with stereotypes. However, if we keep repeating the process of copying copies, those inaccuracies eventual1y wi11 become a positive characteristic in the copy. But we need to be careful not to reject these originals because they are the ones that open the door to access this process.

As we see in the image of Señor de Huanca, which appeared in Cuzco, Peru, this image has managed to reverse the power of the original. If we trace its visual etymology, this image wi11 take us to the popular biblical theme of christ Gathering his Garments, perhaps closer in its formal qualities to the version of Zurbaran. The image of Señor de Huanca is important not for its similarity to Zurbaran's version, but for its own local importance, thanks to its inaccuracies, because if we do not interrupt the trajectory of the copy, the copy can lead us to an unexpected world of occurrences. The more the copy is copied, the more it wi11 distance itself from the original, becoming closer to its own original. Señor de Huanca is evidence of this process because it has gained and lost formal qualities. This activity of adding and subtracting has defined its identity and increased its value, a type of value that cannot be monitored by the global knowledge. ${ }^{x}$ Because if you touch the painting of Zurbaran you might end up outside of the museum, but if you touch the original copy of senor de Huanca it might concede you a miracle. So if you want to access the magic world of the parafiction come and touch 
an original copy of Senor de Huanca and your wish wi11 be granted. 


\section{NOTES}

i Allan Scott, McKinley. 2006. "The first two centuries of Saint Martin of Tours." Early Medieval Europe 14, no. 2: 173 - 200. Academic Search Premier, EBSCOhost (accessed February 13, 2017). 174

ii Joseph J Rishel and Suzanne L. Stratton-Pruitt. 2006. The arts in Latin America, 14921820. Philadelphia, PA: Philadelphia Museum of Art, 327, 328.

iii Mario Vargas LLosa writes in the presentation to Don Quixote for its IV centenary a short essay 'A novel for the XXI century'. Vargas LLosa mentions that the main character, Alonso Quijano, creates Don Quixote not to revisit or bring back the past. He is doing something much more ambitions. Quijano created Don Quixote to make the myth and the fiction a reality. Cervantes Saavedra, Miguel de, and Francisco Rico. 2004. Don Quijote de la Mancha. Madrid: Real Academia Española, XIV.

iv Some sentences of this paragraph were copied and adapted from the interview in NPR with Jon Sarkin. The purpose is to create a parallel between Sarkin's tragic experience and History. After a stroke, Sarkin lost his identity and became a compulsive painter. But strangely he still remembers he was a chiropractor and who he was before the stroke. But as he says in the interview he does not want to entertain that question, because it makes him sad. "Jon Sarkin: When Brain Injuries Transform Into Art." NPR. April 18, 2011. Accessed February 13, 2017. http://www.npr.org/templates/transcript/transcript.php?storyId=135509114.

v “...The Americas produced a river of silver...For those centuries Spanish silver washed around the planet - it was 80 percent or more of the world's output - overwhelming governments and financial institutions every where it landed." Mann, Charles C. 2011. 1493: uncovering the new world Columbus created. New York: Knopf, 189.

vi "Not only did the Columbian Exchange carry the ultra-productive potato to Europe and North America, it also brought ultra-productive Andean potato-cultivation techniques, including the world's first intensive fertilizer: Peruvian guano.” Ibid., 253.

viii The Casta paintings appeared in the $18^{\text {th }}$ century. The intention behind the paintings was to categorize people and create ethnic separations using other elements such as clothing, social environment, and interactions with their surroundings. Rishel, Joseph J., and Suzanne L. Stratton-Pruitt. 2006. The arts in Latin America, 1492-1820.

Philadelphia, PA: Philadelphia Museum of Art, 403.

ix Person, and Francis X. Rocca. "The Power of Mexico's Version of the Virgin Mary." WSJ. Accessed March 03, 2016. http://www.wsj.com/articles/the-power-of-mexicosversion-of-the-virgin-mary-1455294703\#:qo6WobWTQMWE2A.

${ }^{x}$ Antonio Rafael Fernandez Paradas and Rubén Sánchez Guzmán, José Luis Crespo Fajardo, and Samuel Toledano. 2012. Origenes, desarrollos y difusion de un modelo 
iconografico: Jesus recogiendo sus vestiduras despues de la flafelacion (siglos $X V$-XX). Tenerife: Sociedad Latina de Comunicación Social, 99.

xi Ibid., 31.

xii Ibid., 98.

xiii Michael Sallnow. 1982. "a trinity of Christs: cultic processes in Andean Catholicism".American Ethnologist. 9 (4): 736

xiv The information about the myths were taken and summarized from the work of Guillermo Eyzaguirre. Luis Guillermo Márquez Eyzaguirre. 1936. Huanka rumi; historia de las apariciones del señor de Huanca y de su celebre santuario. Cuzco: Tip. Americana, 42-110.

${ }^{\mathrm{xv}}$ Ibid., 45.

xvi The information about Diego Alvarez de la Paz was taken from the following source: "Misión Jesuita Peruana." Misión Jesuita Peruana. Accessed November 30, 2015. http://www.misionjesuitaperuana.com/\#!la-misin-en-el-per/c25l.

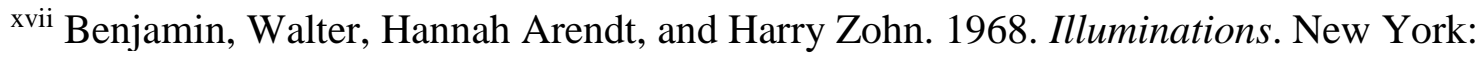
Harcourt, Brace \& World, 254.

xviii Michel, Foucault, Mauro Bertani, Alessandro Fontana, François Ewald, and David Macey. Society Must Be Defended: Lectures at the Collège De France, 1975-76. New York: Picador, 2003, 6.

${ }^{\text {xix }}$ Don Santo, Colonial Photoshop Software Manual. 8.

xx Ibid., 10.

xxi Carrie, Lambert-Beatty. "Make-Believe : Parafiction and Plausibility." October 129 (2009): 51-84. http://www.jstor.org/stable/40368563, 60.

xxii Ibid., 54.

xxiii José Carlos Mariátegui. 1971. Seven interpretive essays on Peruvian reality. Austin: University of Texas Press, 134.

xxiv Carlos, Fuentes. 1992. The buried mirror: reflections on Spain and the New World, $144,146$.

${ }^{\mathrm{xxv}}$ STANFIELD-MAZZI, MAYA. 2013. Object and Apparition Envisioning the Christian Divine in the Colonial Andes. TUCSON: University of Arizona Press. (102). 
xxvi Ibid., (99).

xxvii Jose de Mesa and Teresa Gisbert. "Angelic Ways." Franco MariaRicci (FMR), no. 85 (1997): 32 .

xxviii Katzew, Ilona, and Luisa Elena Alcalá. 2011. Contested visions in the Spanish colonial world. Los Angeles: Los Angeles County Museum of Art. 240.

xxix Joseph J Rishel and Suzanne L. Stratton-Pruitt. 2006. The arts in Latin America, 1492-1820. Philadelphia, PA: Philadelphia Museum of Art. 331.

${ }^{x x x}$ Kennedy, Dane Keith. 2016. Decolonization: a very short introduction. 98.

${ }^{x x x i}$ For the French Philosopher Roland Barthes, myths are constructed narratives that are made to be understood as real and universal narratives according to the members of a particular society. Sturken, Marita, and Lisa Cartwright. 2009. Practices of looking: an introduction to visual culture. New York: Oxford University Press. 20.

xxxii STANFIELD-MAZZI, MAYA. 2013. Object and Apparition Envisioning the Christian Divine in the Colonial Andes. TUCSON: University of Arizona Press. 74.

xxxiii Other authors indicate that when the image was carried on a procession the earthquakes stopped. Palmer, Gabrielle G., and Donna Pierce. 1992. Cambios: the spirit of transformation in Spanish colonial art. [Santa Barbara, Calif.]: Santa Barbara Museum of Art in cooperation with University of New Mexico Press. 31.

xxxiv The information about the myths was taken from this source that it is in Spanish. Gonzalo, Haristoy. "Las historias paranormales tras el Cristo de mayo." Cristo de mayo: entre mitos, temblores y milagros | Noticias Santiago | CIVICO.com. January 27, 2017. Accessed February 01, 2017. https://www.civico.com/santiago/noticias/cristo-de-mayoentre-mitos-temblores-y-milagros.

${ }^{\mathrm{xxxv}}$ STANFIELD-MAZZI, MAYA. 2013. Object and Apparition Envisioning the Christian Divine in the Colonial Andes. TUCSON: University of Arizona Press. 119.

${ }^{x x x v i}$ Katzew, Ilona, and Luisa Elena Alcalá. 2011. Contested visions in the Spanish colonial world. Los Angeles: Los Angeles County Museum of Art. 229.

xxxvii Edward W, Said. 1993. Culture and imperialism. New York: Knopf. 16.

xxxviii Katzew, Ilona, and Luisa Elena Alcalá. 2011. Contested visions in the Spanish colonial world. Los Angeles: Los Angeles County Museum of Art. 243.

xxxix Ibid., 201. 
${ }^{\mathrm{xl}}$ Katzew, Ilona, and Luisa Elena Alcalá. 2011. Contested visions in the Spanish colonial world. Los Angeles: Los Angeles County Museum of Art. 179.

xli Jean, Baudrillard. 1983. Simulations. New York City, N.Y., U.S.A.: Semiotext(e), Inc. 89.

xlii Ibid., 91.

xliii Ibid., 1.

xliv Jay, Martin, and Sumathi Ramaswamy. 2014. Empires of vision: a reader. 497.

${ }^{\mathrm{xlv}}$ Scott, James C. 1998. Seeing like a state: how certain schemes to improve the human condition have failed. New Haven: Yale University Press. 313.

xlvi Ibid., 316.

xlvii Homi, Bhabha. "Of Mimicry and Man: The Ambivalence of Colonial

Discourse." October 28 (1984): 125-33. doi:10.2307/778467. 126.

xlviii Ibid. 127.

xlix Ibid. 126.

${ }^{1}$ Many colonial paintings have their origins on mistakes. The artists eliminated what they did not understand or simply adapted it to their knowledge. For instance, Carolyn Dean mentions how some paintings of carts were altered because the locals had no idea of what they were copying. That's why the image of Jose Gaudi, "Cart of the Tailors" looks more like an organ. In another painting "Corpus Christi Procession: Parish of the hospital de los Naturales" the document from the person holding it has disappeared. Now it looks like he is singing.

Carolyn S. 1996. "Copied carts: Spanish prints and colonial Peruvian paintings." Art Bulletin 78, no. 1: 98. Academic Search Premier, EBSCOhost (accessed December 13, 2016). 102

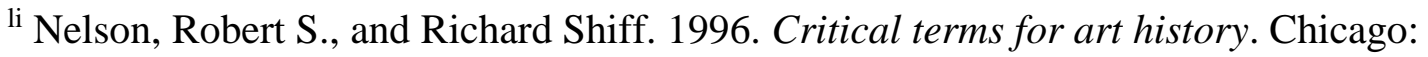
University of Chicago Press. 33.

lii Ibid.

liii During the beginnings of the $20^{\text {th }}$ century silent films were very popular in the US. However, in a research conducted by the library of congress many of these movies did not survived, they calculate that $70 \%$ of these films are completely lost. But thanks to the historian and composer Ben Modell, Some of the old films were saved due to what he calls 'Accidentally Preserved." He explains that companies in the 30s made copies for the people who wanted to watch it at home. The irony is that those copies had managed to 
survive the pass of time while the originals have not. Perhaps this is the evidence of how the history of western cultures was built.

Matheson, Whitney. "'Accidentally Preserved': Rare silent films come to DVD." USA

Today. January 22, 2014. Accessed February 14, 2017.

http://www.usatoday.com/story/popcandy/2014/01/21/silent-films-dvd/4721515/.

liv Homi K, Bhabha. 1994. The location of culture. London: Routledge. 72.

${ }^{1 v}$ Gruzinski, Serge, and Heather MacLean. 2001. Images at war: Mexico from Columbus to Blade Runner (1492-2019). Durham: Duke University Press. 163.

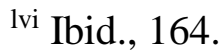

lvii Ibid., 163.

Iviii Jay, Martin, and Sumathi Ramaswamy. 2014. Empires of vision: a reader. 477.

lix Ibid., 486.

1x The image of Señor de Huanca is very popular in Cuzco, Peru. However, this popularity did not stop other images from appearing as well. In fact, one of them is 'El Señor de la Columna' or 'Lord of the Column'. Painted around the $18^{\text {th }}$ century. It is an image that has many similarities with the iconography of the image of Señor de Huanca. Both images also share the same day for their ceremonies. Besides, the 'Lord of the Column' has its own myths and its own local identity. According to the stories, 'Lord of the Column' was owned by the Ochoa family, therefore the ceremony its called now the 'Ochoadas', meaning something like 'what the Ochoas do'. These coincidences raise the following question: is Lord of the Column a copy of Señor de Huanca or is it a copy of the European versions of the Lord of the Column? However, the peculiar aspect with the Lord of the Column from Cusco is that in 2005 this image was stolen. But its absence did not stop the locals from practicing the ceremony. The people from the locality of Urubamba already commissioned a copy of the Lord of the Column and hope that this is as miraculous as the first one. Http://larepublica.pe. "El Cristo que fue robado."

Larepublica.pe. August 30, 2005. Accessed January 13, 2017. http://larepublica.pe/30-082005/el-cristo-que-fue-robado. 


\section{REFERENCES}

\section{(TO SEE THE REFERENCES OF C.P. CODEX, PLEASE CLICK HERE)}

Baudrillard, Jean. 1983. Simulations. New York City, N.Y., U.S.A.: Semiotext(e), Inc.

Benjamin, Walter, Hannah Arendt, and Harry Zohn. 1968. Illuminations. New York: Harcourt, Brace \& World, 254.

Bhabha, Homi K. 1994. The location of culture. London: Routledge.

Bhabha, Homi. "Of Mimicry and Man: The Ambivalence of Colonial Discourse."October 28 (1984): 125-33. doi:10.2307/778467.

Carolyn S. 1996. "Copied carts: Spanish prints and colonial Peruvian paintings." Art Bulletin 78, no. 1: 98. Academic Search Premier, EBSCOhost (accessed December 13, 2016). 102

Candidulus. "Edward Said on Culture and Imperialism." YouTube. February 09, 2016. Accessed February 14, 2017. https://www.youtube.com/watch?v=-_YU-XmU10.

Carlos, Fuentes. 1992. The buried mirror: reflections on Spain and the New World.

Cervantes Saavedra, Miguel de, and Francisco Rico. 2004. Don Quijote de la Mancha. Madrid: Real Academia Española, XIV.

Don Santo, Colonial Photoshop Software Manual.

Fernandez Paradas, Antonio Rafael, Rubén Sánchez Guzmán, José Luis Crespo Fajardo, and Samuel Toledano. 2012. Origenes, desarrollos y difusion de un modelo iconografico: Jesus recogiendo sus vestiduras despues de la flafelacion (siglos XV-XX). Tenerife: Sociedad Latina de Comunicación Social.

Foucault, Michel, Mauro Bertani, Alessandro Fontana, François Ewald, and David Macey. Society Must Be Defended: Lectures at the Collège De France, 1975-76. New York: Picador, 2003.

Gonzalo, Haristoy. "Las historias paranormales tras el Cristo de mayo." Cristo de mayo: entre mitos, temblores y milagros | Noticias Santiago | CIVICO.com. January 27, 2017. Accessed February 01, 2017. https://www.civico.com/santiago/noticias/cristo-de-mayo-entre-mitos-temblores-ymilagros.

Gruzinski, Serge, and Heather MacLean. 2001. Images at war: Mexico from 
Columbus to Blade Runner (1492-2019). Durham: Duke University Press.

Http://larepublica.pe. "El Cristo que fue robado." Larepublica.pe. August 30, 2005. Accessed January 13, 2017. http://larepublica.pe/30-08-2005/el-cristo-que-fue-robado.

Jay, Martin, and Sumathi Ramaswamy. 2014. Empires of vision: a reader.

"Jon Sarkin: When Brain Injuries Transform Into Art." NPR. April 18, 2011. Accessed February 13, 2017. http://www.npr.org/templates/transcript/transcript.php?storyId=135509114.

Jose de Mesa and Teresa Gisbert. "Angelic Ways." Franco MariaRicci (FMR), no. 85 (1997): 32.

Katzew, Ilona, and Luisa Elena Alcalá. 2011. Contested visions in the Spanish colonial world. Los Angeles: Los Angeles County Museum of Art.

Kennedy, Dane Keith. 2016. Decolonization: a very short introduction.

La Matriz. CODEX MANUAL.

Lambert-Beatty, Carrie. "Make-Believe : Parafiction and Plausibility." October 129 (2009): 51-84. http://www.jstor.org/stable/40368563.

Mariátegui, José Carlos. 1971. Seven interpretive essays on Peruvian reality. Austin: University of Texas Press.

Mann, Charles C. 2011. 1493: uncovering the new world Columbus created. New York: Knopf.

Márquez Eyzaguirre, Luis Guillermo. 1936. Huanka rumi; historia de las apariciones del señor de Huanca y de su celebre santuario. Cuzco: Tip. Americana, 42.

Matheson, Whitney. "'Accidentally Preserved': Rare silent films come to DVD." USA Today. January 22, 2014. Accessed February 14, 2017. http://www.usatoday.com/story/popcandy/2014/01/21/silent-films-dvd/4721515/.

McKinley, Allan Scott. 2006. "The first two centuries of Saint Martin of Tours.” Early Medieval Europe 14, no. 2: 173 - 200. Academic Search Premier, EBSCOhost (accessed February 13, 2017).

"Misión Jesuita Peruana." Misión Jesuita Peruana. Accessed November 30, 2015. http://www.misionjesuitaperuana.com/\#!la-misin-en-el-per/c25l. 
Nelson, Robert S., and Richard Shiff. 1996. Critical terms for art history. Chicago: University of Chicago Press.

Palmer, Gabrielle G., and Donna Pierce. 1992. Cambios: the spirit of transformation in Spanish colonial art. [Santa Barbara, Calif.]: Santa Barbara Museum of Art in cooperation with University of New Mexico Press.

Person, and Francis X. Rocca. "The Power of Mexico's Version of the Virgin Mary." WSJ. Accessed March 03, 2016. http://www.wsj.com/articles/the-power-of-mexicosversion-of-the-virgin-mary-1455294703\#:qo6WobWTQMWE2A.

Rishel, Joseph J., and Suzanne L. Stratton-Pruitt. 2006. The arts in Latin America, 1492- 1820. Philadelphia, PA: Philadelphia Museum of Art.

Said, Edward W. 1993. Culture and imperialism. New York: Knopf.

Scott, James C. 1998. Seeing like a state: how certain schemes to improve the human condition have failed. New Haven: Yale University Press.

SALLNOW, M. J. 1982. "a trinity of Christs: cultic processes in Andean Catholicism".American Ethnologist. 9 (4): 730-749.

STANFIELD-MAZZI, MAYA. 2013. Object and Apparition Envisioning the Christian Divine in the Colonial Andes. TUCSON: University of Arizona Press.

Sturken, Marita, and Lisa Cartwright. 2009. Practices of looking: an introduction to visual culture. New York: Oxford University Press. 